\title{
Geochemical composition of sapropel in lakes: reflections of paleoenvironmental conditions and anthropogenic influence
}

Jonas Satkūnas ( $\sim$ jonas.satkunas@lgt.lt )

Vilnius University https://orcid.org/0000-0002-8229-6276

Vaidotas Valskys

Vilniaus Universitetas

Gytautas Ignatavičius

Vilniaus Universitetas

Alma Grigienè

Lithuanian Geological Survey

Research article

Keywords: Sapropel, Lakes geochemistry, Heavy metals, Paleoenvironment

Posted Date: February 17th, 2020

DOI: https://doi.org/10.21203/rs.2.23637/v1

License: (9) This work is licensed under a Creative Commons Attribution 4.0 International License.

Read Full License 


\section{Abstract}

Geochemical and lithological parameters of sapropel in lakes, combined with pollen data and radiocarbon ${ }^{14} \mathrm{C}$ datings, contain a wide spectrum of environmental information. This includes records of fluctuations of water level and changes of conditions of sedimentation, accumulation of organic matter and chemical elements due to climate change, human impacts and other environmental changes. Four lakes with different trophic states and anthropogenic pressures were chosen for this study in Lithuania. Lake Balsys has a mesotrophic state while Lakes Didžiulis, Salotė and Gineitiškès have eutrophic states. X-ray fluorescence spectrometry was used to analyse concentrations of chemical elements, loss-onignition to determine organic, mineral and carbonate matter, pollen analysis and radiocarbon dating were applied for determination of paleoenvironmental conditions and age of sediments. Results of this study demonstrated rather different chemical compositions of sapropels in these lakes. Human impacts are evident in the upper layers of sapropel in all lakes, however very specific and complex geochemical composition was determined in deeper layers of sapropel in the different lakes. Higher concentrations of elements like $\mathrm{Cr}$ and $\mathrm{Zn}$ are expected in deeper layers of sapropel and are attributed to lithogenic association of trace elements. $\mathrm{Pb}$ and $\mathrm{Cu}$ were detected in upper layers of sapropel which indicates the impact of anthropogenic activity. Sapropel of eutrophic lakes (Salotė and Gineitiškès) is enriched by high concentrations of heavy metals (galbūt naudoti tiesiog chemical elements?) ( $\mathrm{Pb}, \mathrm{Cr}, \mathrm{Cu}, \mathrm{Zn}$ ). Their main source was multidimensional anthropogenic pollution leading to a biogenic-anthropogenic association of elements. Sapropel with low concentrations of heavy metals exhibits a different inter-association matrix because most of the elements tend to form lithogenic-clastogenic associations.

\section{Introduction}

Lakes continuously accumulate sediments after the formation of their basins (kettle holes) and the time for development can last for several thousand years or even longer, dependent on paleoenvironmental conditions. These sediments are formed from biological remains originating in the lake and its catchment area as well as soil particles and other non-biological materials that were transported to the lake from the territory of the river basin and from atmosphere. One type of sediment that is commonly found in lakes in the North Temperate Zone is sapropel which is a type of fine organogenic sediment (Bradley 1999; Kurzo et al. 2004; Stankevica and Klavins 2013). According to the classification of lacustrine sediments used in Lithuania (Order ...2016), the sapropel is water laid very fine material containing more than $15 \%$ of organic matter and, depending on the amount of admixture, can be organic, carbonatic, sandy, silty or clayey.

Analysis of sapropel composition is important for determination of its quality as potential raw material, impact of anthropogenic activity and also paleoenviromental conditions and dynamics of lake ecosystems. Sediments are formed under interaction of biological, chemical and physical processes that take place in the catchment area and lake itself. The intensity and combination of these processes are very variable depending on the different geological and geomorphological settings, hydrological regimes 
and atmospheric conditions, as well as human activities (Bigler et al. 2002; Stankevica et al. 2015; Chondrogianni et al. 1996).

Hydroclimatic conditions essentially influence the manner and intensity of transport of lithogenic elements from the catchment area to the lake. Dry periods with sparse vegetation cover may cause an increase of physical weathering. During warm and wet periods, chemical weathering might be induced. Greater amounts of dust are transported during physical weathering which is more intense during cold periods with limited vegetation cover (deforestation, intensity of agriculture and etc.). Concentrations of trace metals are usually affected by anthropogenic atmospheric deposition. These different conditions influence changes of geochemistry in sediments (Brännvall et al. 2001; Koinig et al. 2003; Shotyk 1988). In addition to geochemical composition of sapropels, pollen analysis is very important as it provides information about vegetation cover in the catchment area of the lake, it allows reconstruct dynamics of past vegetation and provides climatostratigraphical data for determination of age of sediments (Gryguc et al. 2013; Rūtina et al. 2012; Heikkila and Seppa 2010).

Concentrations of heavy metals in sapropel layers can be very uneven. Most of dissolved heavy metals before settling to the bottom sediments are in colloidal or suspended phases in the aquatic systems of the lakes. Heavy metals in such environments can accumulate in high concentrations and become toxic for water organisms (Tylmann et al. 2011; de Boer et al. 2001; Ong et al. 2013; Moller et al. 2012). Heavy metals which enter aquatic environments typically bond with bottom sediments and, thus over time, can reach high concentrations. In these circumstances heavy metals can become a potential risk to human health through the food chain. Moreover, high concentrations of heavy metals pose a potential ecological hazard. Changes of hydrodynamic conditions, biological activities, and physical and chemical conditions can lead to secondary pollution. The cause of the high concentrations of heavy metals in sediments may also be due to natural environmental (lithological sources, erosion and etc.) conditions (Arnaboldi and Meyers 2007; Canavan et al. 2007; Zhu et al. 2005; Leonova et al. 2014; Lepane et al. 2007; Mimba et al. 2018).

Sapropel can be used in agriculture, livestock farming, medicine and construction industry etc. Recently the extraction and use of sapropel has increased, thus it is of great importance to carry out detailed researches on the geochemical composition of sapropel but there is currently a lack of detailed studies of geochemical composition of these deposits, especially in Lithuania. Research is required to both provide the information about conditions of the formation of sapropel, but also detailed composition in terms of chemical elements. This is important as sapropel is extracted from the top-most layers to the deeper layers. The aim of this study to analyse and evaluate processes that took place during the formation of sapropel in lakes in Lithuania and geochemical composition that is influenced and determined by those processes.

\section{Materials And Methods}

Study area 
Four lakes with different trophic levels and anthropogenic pressures were selected for this study (Fig. 1, Table 2). All lakes are situated within the area of Late Weichselian Glaciation in the eastern part of Lithuania (Guobytė and Satkūnas 2011) and sedimentation history in their basins span from Late Glacial through Holocene until modern times.

Lake Balsys covers $0.55 \mathrm{~km}^{2}$ area with average depth of $15.2 \mathrm{~m}$. This lake is a typical deep glaciokarstic tunnel valley originating after melting of an ice block buried under glaciofluvial sediments. The surroundings of the lake are formed by sandy hills dissected by numbers of ravines. This lake is situated in Verkiai Regional Park. Its catchment area is forested, semi-natural with minimal load of anthropogenic activity. The lake has one outflow and inflow but is mainly groundwater-fed complemented by rainfall and surface runoff. Hydrochemical characteristics of Lake Balsys are: average dissolved oxygen concentration $-8.1 \mathrm{mg} / \mathrm{L} \mathrm{O}_{2}, \mathrm{pH}-8.5$, clarity $-3.5 \mathrm{~m}$, suspended particles $-1.9 \mathrm{mg} / \mathrm{L}$, electric conductivity $-347.5 \mu \mathrm{S} / \mathrm{cm}$.

Lake Didžiulis covers $0.87 \mathrm{~km}^{2}$ area with average depth of $6.5 \mathrm{~m}$. The kettle hole of the lake was formed when block of inactive ice was left by a melting glacier of the Late Weichselian glaciation. The lake is surrounded by high morainic hills. The catchment area of this lake is occupied mostly by agricultural land in which there are several small settlements and farmsteads. The Vilnius-Kaunas highway passes close to the southern shore of the lake. The lake is popular for fishing, especially in winter time. It has three inflows and one outflow. It is mostly groundwater-fed complemented by rainfall and surface runoff. The hydrochemical characteristics of Lake Didžiulis are: average dissolved oxygen concentration - $9.1 \mathrm{mg} / \mathrm{L}$ $\mathrm{O}_{2}, \mathrm{pH}-8.4$, clarity $-1.2 \mathrm{~m}$, suspended particles $-4.8 \mathrm{mg} / \mathrm{L}$, electric conductivity $-432 \mu \mathrm{S} / \mathrm{cm}$.

Lake Salote covers $0.13 \mathrm{~km}^{2}$ area with average depth of $1.8 \mathrm{~m}$. The origin of the kettle hole is complex glacial-glaciofluvial and surrounded by slightly undulating relief composed of sandy sediments and glacial clayey loam (to the eastern side of the lake). The catchment area had been recently urbanized (a suburb of Vilnius City). The lake is very popular for bathing in summer time. It has one inflow and one outflow. Mostly this lake is fed by rainfall, surface runoff and groundwater. The hydrochemical characteristics of Lake Salote had not then been observed.

Lake Gineitiškès covers $0.13 \mathrm{~km}^{2}$ area with average depth of $1.8 \mathrm{~m}$. The basin is of glacial origin. The relief north of the lake is composed of glacial loam (till) and on the other sides by sandy glaciofluvial formations. The lake is situated in the centre of Gineitiškès village, which is now a western suburb of Vilnius City. The lake has one inflow and one outflow. It is mostly fed by rainfall, surface runoff and groundwater. The hydrochemical characteristics of Lake Gineitiškès had not yet been observed.

All of these lakes are situated in a fairly small area so there is no difference in climatic conditions that could influence conditions of sapropel accumulation. However, deposition is dependent on the topography and lithological composition of surroundings of the lake, the hydrological regime, soils and vegetation types. 
The depth of shallow (unconfined) groundwater in the vicinities of all of these lakes varies from 5 to 1 meter and depends on morphology of the kettle hole (Groundwater of Lithuania, 2018) thus stable alimentation by groundwater is provided for the hydrological regime of the lakes. The average annual $\mathrm{pH}$ values of lakes that are $<4 \mathrm{~m}$ in depth are 8.07, maximum -9.5 and minimum -4.52 . The average annual $\mathrm{pH}$ values of lakes that are $>4 \mathrm{~m}$ in depth are 8.1 , maximum -9.8 and minimum -6.32 . There are no anomalies of geochemical contamination recorded (Kadūnas et al. 1999). There are few potential pollution sources in the catchment areas of Lakes Gineitiškès, Salotė and Didžiulis. Mostly these are industrial yards, garages or former farms, but there is no heavy industry (plants, factories, etc.). Such potential pollution sources cause the intensified migration of chemical elements from catchment area and thus enrichment of lake sediments with heavy metals $(\mathrm{Zn}, \mathrm{Cu}, \mathrm{Cr}, \mathrm{Pb})$ as well as lithogenic elements $(\mathrm{Zr}, \mathrm{Sr}, \mathrm{Rb})$.

\section{Coring and sampling}

The lakes are open systems, the physicochemical characteristics and dynamics of which are determined by interrelated factors: the morphometrical features (the depth, the area, the water volume), the slope and bottom morphology, the trophic state, the catchment size, the groundwater interactions, the climatic conditions and the flow input (Schnurrenberger, 2003). The most important factor for securing appropriate and representative samples of sapropel is the bottom morphology. Sampling points were selected in flat parts of lake depressions to ensure even sedimentation conditions and processes. For this purpose, available bathymetry plans were digitized using "ArcMap" software and used for precise selection of sampling points.

All kettle holes of lakes are located in Quaternary glacial formations the general thickness of which is 80100 metres (dependent on the elevation of topography). Pre-Quaternary bedrock occurs under the Quaternary cover but the bottoms of kettle holes do not reach it. The base of lacustrine sediments was penetrated by borings only in Lake Salotè.

Coring was done from ice at selected drilling points. Sediment coring was carried out using a $10 \mathrm{~cm}$ diameter sampler with a $0.5 \mathrm{~m}$ long camera. The cored sediment thickness reached $2.6 \mathrm{~m}$ in Lake Salote, $3.0 \mathrm{~m}$ in Lake Balsys, $3.0 \mathrm{~m}$ in Lake Didžiulis and $9.1 \mathrm{~m}$ in Lake Gineitiškès. The thicknesses of sediment cores vary due to technical possibilities (length of borer and water column). In each case, three parallel overlapping sediment cores were documented according to the requirements (Domaševičius et al. 1999) and packed into plastic bags and transported to the laboratory for physical, chemical and pollen analyses.

The thickness of the sediments in the lakes, depth and rate of contamination were not known before the beginning of investigations. Therefore it was not possible to foresee the total number of samples at the outset. Following the logging recommendations for environmental investigations (Domaševičius et al. 1999) it was decided to take samples with an optimal spacing of $10 \mathrm{~cm}$ assuming that this frequency would be adequate enough to determine stratigraphy of the sections and detect traces of possible 
anthropogenic contamination. Accordingly, sapropel cores were sampled with at intervals of $10 \mathrm{~cm}$ and 356 samples were analysed in total.

X-ray fluorescence spectrometry

Samples were dried at $105^{\circ} \mathrm{C}$ to a constant mass, then the particles of $<125 \mu \mathrm{m}$ size were separated and concentrations of heavy metals were analysed using an X-ray fluorescence spectrometer Niton XL2 Analyzer (2009). The total relative analytical error was within $5 \%$. The device was used only in a stand at laboratory and 600 seconds of analysis time was selected to achieve the highest accuracy that could be achieved. The overall accuracy of analysis of chemical elements varies from $10 \%(\mathrm{Cr}, \mathrm{Cu}, \mathrm{Zn}, \mathrm{Zr}, \mathrm{Sr}, \mathrm{Rb}$, $\mathrm{Mn}, \mathrm{Fe}$ ) to $20 \%$ (As, Pb, Cd, Hg). Furthermore, this device was inter-calibrated with an atomic absorption spectrometer and results were found to be up to $20 \%$ of significant systematic difference.

Loss-on-ignition (LOI)

This method was applied in order to determine the content of moisture, organic matter and mineral matter. A $5 \%$ solution of $\mathrm{HCl}$ was used to estimate the content of carbonates. The moisture content in sediment samples was determined after drying at $105^{\circ} \mathrm{C}$ to a constant mass. The content of the organic and carbonate matter was analysed by incinerating the samples at $550{ }^{\circ} \mathrm{C}$ for $4 \mathrm{~h}$ and then using $5 \% \mathrm{HCl}$ solution sequentially.

Pollen analysis

The pollen analysis was undertaken to identify stratigraphical subdivisions of the sections of lake sediments and thus to determine the ages of sapropel layers. The samples for pollen analysis were prepared in the laboratory of the Nature Research Centre in Vilnius according standardized procedures. 500-1000 of pollen grains were counted per sample (except aquatic plant pollen and spores). The basic sum $(100 \%)$ for pollen percentage calculations was based on the sum of all pollen, except the aquatic plant pollen. For processing of pollen data, Tilia 2.0.41 software was used. Comparison of all of the cores of different depth is based on the stratigraphic correlation of sediments subdivided by pollen analyses.

Radiocarbon $\left({ }^{14} \mathrm{C}\right)$ dating

The absolute age of sediments was determined by radioactive carbon $\left({ }^{14} \mathrm{C}\right)$ dating at the Laboratory of Nuclear Geophysics and Radioecology of the Nature Research Centre in Vilnius. 8 samples were dated (Table 1) in total from all boreholes. The results were combined with pollen data and to determine chronozones of sediments.

Table 1 Details of lakes sediment samples that were dated 


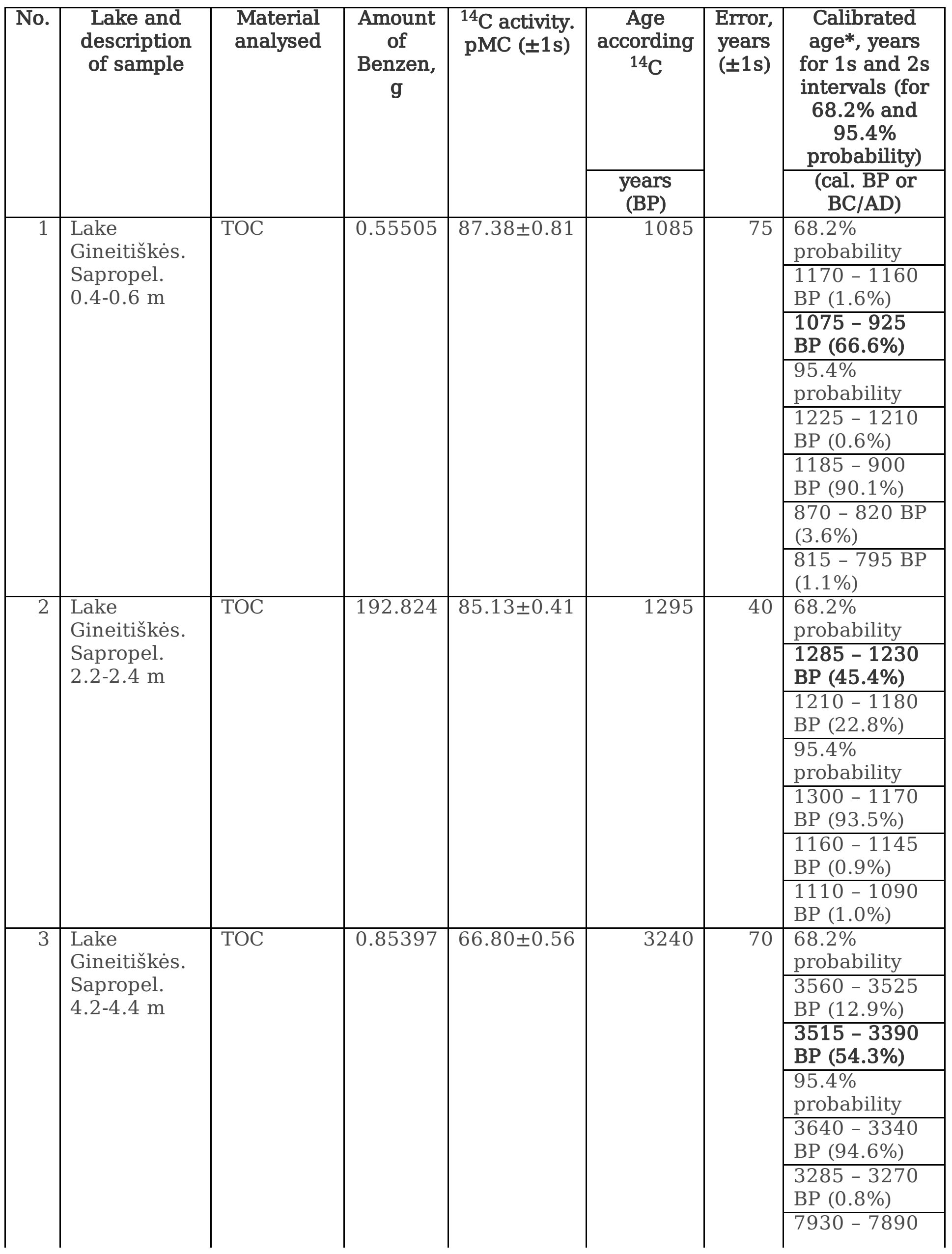




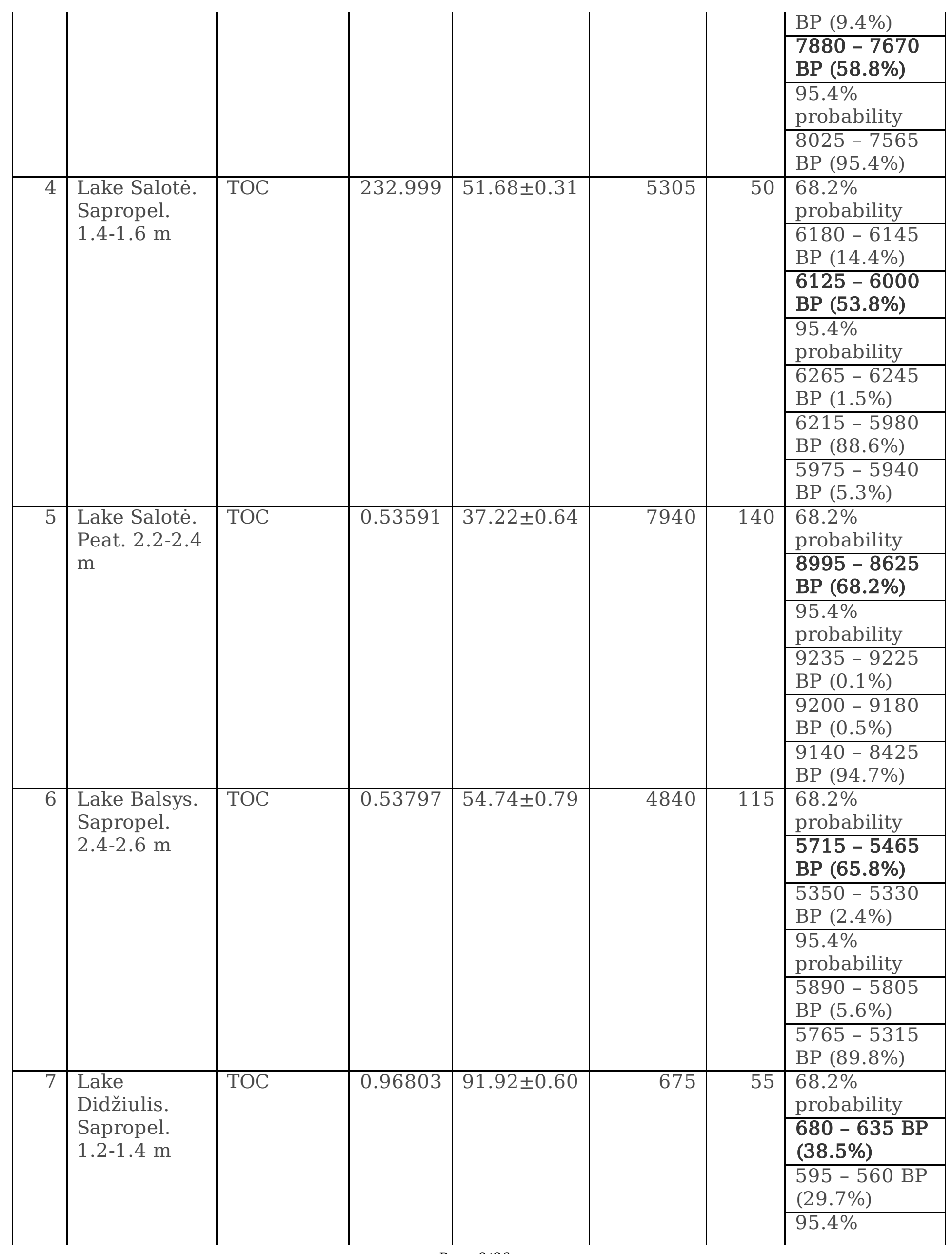




\begin{tabular}{|c|c|c|c|c|c|c|c|}
\hline & & & & & & & $\begin{array}{l}\text { probability } \\
695-540 \mathrm{BP} \\
(95.4 \%)\end{array}$ \\
\hline \multirow[t]{4}{*}{8} & \multirow[t]{4}{*}{$\begin{array}{l}\text { Lake } \\
\text { Didžiulis. } \\
\text { Sapropel. } \\
\text { 3.7-3.9 m }\end{array}$} & \multirow[t]{4}{*}{ Carbonates } & \multirow[t]{4}{*}{0.44382} & \multirow[t]{4}{*}{$33.26 \pm 0.70$} & \multirow[t]{4}{*}{8845} & \multirow[t]{4}{*}{145} & $\begin{array}{l}68.2 \% \\
\text { probability } \\
10160-9735 \\
\text { BP }(67.5 \%)\end{array}$ \\
\hline & & & & & & & $\begin{array}{l}9715-9710 \\
\text { BP }(0.7 \%)\end{array}$ \\
\hline & & & & & & & $\begin{array}{l}95.4 \% \\
\text { probability }\end{array}$ \\
\hline & & & & & & & $\begin{array}{l}10230-9550 \\
\text { BP }(95.4 \%)\end{array}$ \\
\hline
\end{tabular}

* Program for calibration - OxCal 4.2 (Bronk Ramsey C., 2013).

* Curve for calibration - IntCal2013 (Reimer P.J. et al., RADIOCARBON, Vol 55, No. 4, 2013, p 1869-1887).

Statistical methods

Data on concentrations of heavy metals were analysed using an XLSTAT statistical package. Agglomerative Hierarchical Clustering (AHC) was used as the clustering (or classification) method which determines dissimilarities between the objects to be grouped together. As a statistical method, a Spearman correlation model was used as it is a non-parametric method which is the most suitable for environmental sciences. As a result, chemical elements were visualized as dendrograms which show the progressive grouping of the data. It makes possible to gain an idea of a suitable number of classes into which the data can be grouped.

\section{Results}

Results of the analyses are presented in order according to the anthropogenic conditions of locations of the catchments of lakes:

First group: Lakes Balsys and Didžiulis are situated in semi-natural environments with minimum pressure of anthropogenic activities.

Second group: Lakes Salotė and Gineitiškès are situated in environments with moderate and intense anthropogenic activity depending on the degree of urbanisation of surroundings. The anthropogenic influence is demonstrated by elements such asCr for which a concentration up to 1.7 times exceeds the maximum allowable concentration (MAC) (LME 2014) in modern sediments of Salote and up to 3.17 times in Gineitiškès (Table 2). Furthermore, Zn concentrations up to 1.5 times exceed the MAC in Salote. High $\mathrm{Cr}$ concentrations in most of cases are distributed in upper layers of sediments due to anthropogenic activity (sewage and rain water inflow, leaks from garages, intensive traffic and etc.). 
However, deeper layers can also be enriched with $\mathrm{Cr}$ due to formation of acidic environments which mostly form in shallow lakes during warm and dry periods.

Table 2 The comparison of minimum, average and maximum values of $\mathrm{Pb}, \mathrm{Cr}$, $\mathrm{Cu}$ and $\mathrm{Zn}\left(\mathrm{mg} \cdot \mathrm{kg}^{-1}\right)$ with maximum allowable concentrations (MAC) in bottom sediments of surface water bodies (LME 2014). LOD - level of detection

\begin{tabular}{|c|c|c|c|c|c|c|}
\hline & & & \multicolumn{4}{|c|}{ Metals } \\
\hline & \multirow{2}{*}{\multicolumn{2}{|c|}{ MAC in $\mathrm{mg} \cdot \mathrm{kg}^{-1}$}} & $\mathrm{~Pb}$ & $\mathrm{Cr}$ & $\mathrm{Cu}$ & $\mathrm{Zn}$ \\
\hline & & & 140 & 140 & 75 & 300 \\
\hline Lake & Trophic state & & & & & \\
\hline \multirow[t]{3}{*}{ Balsys } & Mesotrophic & Min. & $<\mathrm{LOD}$ & $<\mathrm{LOD}$ & $<\mathrm{LOD}$ & $6.18 \pm 7$ \\
\hline & & Avg. & $<\mathrm{LOD}$ & $<\mathrm{LOD}$ & $<\mathrm{LOD}$ & $26.94 \pm 7$ \\
\hline & & Max. & $<\mathrm{LOD}$ & $<$ LOD & $<$ LOD & $54.55 \pm 7$ \\
\hline \multirow[t]{3}{*}{ Didžiulis } & Eutrophic & Min. & $<\mathrm{LOD}$ & $<\mathrm{LOD}$ & $<\mathrm{LOD}$ & $10.81 \pm 7$ \\
\hline & & Avg. & $<\mathrm{LOD}$ & $<\mathrm{LOD}$ & $<\mathrm{LOD}$ & $27.69 \pm 7$ \\
\hline & & Max. & $<$ LOD & $<\mathrm{LOD}$ & $<\mathrm{LOD}$ & $114.80 \pm 7$ \\
\hline \multirow[t]{3}{*}{ Salotè } & Eutrophic & Min. & $5.49 \pm 4$ & $18.00 \pm 8$ & $4.89 \pm 8$ & $33.31 \pm 7$ \\
\hline & & Avg. & $13.68 \pm 4$ & $85.43 \pm 8$ & $14.67 \pm 8$ & $139.02 \pm 7$ \\
\hline & & Max. & $19.17 \pm 4$ & $241.04 \pm 8$ & $28.85 \pm 8$ & $446.87 \pm 7$ \\
\hline \multirow[t]{4}{*}{ Gineitiškès } & Eutrophic & Min. & $3.20 \pm 4$ & $22.48 \pm 8$ & $6.51 \pm 8$ & $84.71 \pm 7$ \\
\hline & & Avg. & $12.41 \pm 4$ & $107.48 \pm 8$ & $18.52 \pm 8$ & $161.52 \pm 7$ \\
\hline & & Max. & $38.54 \pm 4$ & $445.21 \pm 8$ & $29.78 \pm 8$ & $266.97 \pm 7$ \\
\hline & & & $\mathrm{LOD}=3$ & $\mathrm{LOD}=7$ & $\mathrm{LOD}=4$ & $\mathrm{LOD}=5$ \\
\hline
\end{tabular}

Lake Balsys was drilled in a bay with a flat bottom. Analysis of concentrations of heavy metals in sediment cores shows that this part of lake was influenced by significant changes in catchment area as well of water regime. Four stages of different sedimentation conditions are observed as the ratio of organic and mineral matter changes considerably (Fig 2). Concentrations of Sr are strongly positively correlated with the amount of mineral matter and negatively with the amount of organic matter. Higher concentrations of $\mathrm{Sr}$ most likely reflect the intensity of soil erosion in the catchment area. $\mathrm{Zn}$ concentrations do not reach the MAC. Changes in $\mathrm{Zn}$ are related with the higher amount of organic matter in deeper layers of sediments, as correlation coefficient $r$ is $0.84, p<0.05$ (Fig 10). Most of the determined chemical elements in sediments are strongly associated with amount of organic matter (Fig. 2) with the one exception of the top layer, where is a low proportion of organic matter and significant increase of concentrations of $\mathrm{Zn}$. This increase might suggest an anthropogenic source. It could be mostly due to airborne dust particles and direct input from surrounding areas with higher intensity of human activity. $\mathrm{Pb}, \mathrm{Cu}, \mathrm{Cr}, \mathrm{Cd}$ were not detected as concentrations were lower than detection limit.

$\mathrm{Mn} / \mathrm{Fe}$ ratios are slightly variable, suggesting changes in the hydrological regime of the lake with phases of formation of standing anoxic bottom water as the fluctuations of Mn/Fe ratio are well correlated with 
oxygen concentrations in lakes (Naeher et al. 2014). The Mn/Fe ratio decrease indicates that deeper layers are formed in anoxic conditions while upper layers are formed in water which was slightly more enriched with oxygen. Such results of chemical elements analysis indicate specific conditions in this part of the lake. This could be influenced by this bay of the lake in some periods (sediment layer from 3.0 to 2.4 meters) forming separately from remainder of the lake sediments due to lower water levels, thus the oxygen saturation was much lower.

The pollen analysis (Fig. 3) shows five local pollen assemblage zones (LPAZ): Pinus-Ulmus, Picea, PinusBetula-Alnus and Quercus-NAP. These zones indicate major changes in vegetation structure in catchment area of Lake Balsys during the formation of sapropel. Sedimentation of deeper layers was less influenced by erosion and surface runoff as vegetation cover was mostly composed by coniferous trees (pine, fir) with admixture of alder, birch, however with weak grass cover. Such pollen structure indicates that sapropel in the interval from 3.0 - $0.2 \mathrm{~m}$ was formed during the Late Atlantic, Subboreal and Subatlantic climatic periods (Kabailiene, 2006).

The radiocarbon $\mathrm{C}^{14}$ dating of the sample from the depth $2.6 \mathrm{~m}$ yield an age of $5715-5465 \mathrm{cal}$ yr BP and this result supports the chronostratigraphical interpretation of the pollen diagram.

The data show that Lake Didžiulis was not influenced by such significant sedimentation changes as Lake Balsys since the ratio of organic and mineral matter remains constant along all of the sediment core (Fig. 4). The values of chemical elements such as $\mathrm{Zr}$, Sr and $\mathrm{Rb}$ reveal slight changes. Only the top-most layer is slightly enriched with $\mathrm{Zn}$ which reaches $114.8 \mathrm{mg} \cdot \mathrm{kg}^{-1}$ but do not exceed the MAC. Other heavy metals were not detected as concentrations were lower than the detection limit. Most of the chemical elements in sediment core are strongly associated (Fig. 10) with organic matter ( $r$ values varies from 0.75 to $0.98, p$ $<0.05$ ). The reduced form of $\mathrm{Fe}$ is less stable in the water column than that of $\mathrm{Mn}$ and consequently $\mathrm{Mn} / \mathrm{Fe}$ ratios in the sediments are low when the sediment becomes anoxic (Davison 1993; Stumm and Morgan 1996; Granina et al. 2004). In this lake, the ratio of $\mathrm{Mn} / \mathrm{Fe}$ is rather constant showing that sediments were formed in similar redox conditions with a trend towards lowering of oxygen concentrations, which could be due to eutrophication and changes in water level during recent decades. Only the upper layers have a higher ratio of $\mathrm{Mn} / \mathrm{Fe}$, which could be because this lake was dammed raising the water level thus giving a higher saturation of oxygen.

The four LPAZ (Fig. 5) were distinguished in the pollen diagram (from the bottom of the section): AlnusCorylus, Pinus-Betula, Picea, Pinus-NAP. The vegetation of the first LPAZ (depth of the core 4.1-3.6 m), especially Alnus, is characteristic of the beginning of the Atlantic chronozone (Kabailiene 2006). However, the radiocarbon ${ }^{14} \mathrm{C}$ dating of the sample from the depth interval 3.9-3.7 $\mathrm{m}$ yielded the age of 10160-9735 cal yr BP which is evidently too old for the Atlantic chronozone (boundaries of this chronozone are calibrated at 8590-5731 yr) (Damušytè, 2011). This discrepancy could explained by admixture of older sediments due to re-deposition as is indicated by presence of herbs and in particular Artemisia and fragments of charcoal in the sediments of the interval under discussion. According to the characteristic 
pollen spectra the second LPAZ (depth 3.6-1.9 m) is attributed to the Subboreal, and the upper two LPAZ (depth 1.9-0.2 m) - to the Subatlantic chronozones.

The radiocarbon ${ }^{14} \mathrm{C}$ dating of the sample from the depth $1.2 \mathrm{~m}$ yielded an age of $680-635 \mathrm{cal} \mathrm{yr} \mathrm{BP}$, a date that supports this interpretation. Therefore, the section of sediments of Lake Didžiulis differs from that of Lake Balsys, as in Didžiulis there is much thicker layer of younger sediments. Local pollen assemblage zones of these sediments indicate a colder and dryer climate with an increase of herbs (especially in the uppermost LPAZ, from $1.1 \mathrm{~m}$ depth upwards) in environs of the lake that in turn could have result in an increase of soil erosion. However changes in ratio of organic and mineral matter of these sediments are minor.

Lakes Salote and Gineitiškès are situated in urbanized areas, thus the variety of heavy metals is higher with the presence of $\mathrm{Pb}, \mathrm{Cr}, \mathrm{Cu}$. These elements were not detected in Lakes Balsys and Didžiulis. The highest $\mathrm{Zn}$ concentrations were detected in sapropel layers at depths of 1.7-2.0 m. and values of $\mathrm{Zn}$ reach $446.87 \mathrm{mg} \mathrm{kg}^{-1}$, which exceed the MAC. Such high concentrations in deeper natural layers could be explained by influence of clay material that occurs just below the sapropel (Fig 7). Sapropel is a receptive sorbtion material so it could sorb $\mathrm{Zn}$ from clay minerals. It can be assumed that variations of concentrations of $\mathrm{Rb}, \mathrm{Ti}, \mathrm{Zr}, \mathrm{Fe}, \mathrm{As}$, and $\mathrm{Pb}$ are closely related to respective concentrations of quartz and clay minerals. They are thus considered to represent the silicate fraction which shows an increase from the oldest to the youngest core section (Koinig 2003; Gehrke et al. 2009). In Lake Salote a layer of such clay is beneath $2.0 \mathrm{~m}$ of sapropel and peaty sapropel. Nevertheless, sapropel in Salotè is rich with organic matter and the main associations of chemical elements are formed by lithogenic elements as correlation coefficients vary from 0.74 to $0.98(p<0.05)$ for the most of the elements (Fig. 11).

Concentrations of $\mathrm{Pb}$ and $\mathrm{Cu}$ are only detected in upper layers of sapropel, thus it clearly shows the impact of human activity. $\mathrm{Cr}$ concentrations up to 1.7 times exceed the MAC in upper and bottom layers of sapropel. High concentrations of $\mathrm{Cr}$ in the upper layer are evident as an impact of urban factors while bottom layers are enriched through natural processes linked to the underlying clay formation.

Significant changes of concentrations of chemical elements were also influenced by high variety of redox conditions as shown by the ratio of $\mathrm{Mn} / \mathrm{Fe}$ which changes from bottom to the top of the sediment layers (Fig. 6). The deepest layers were formed with a highly oxygen saturated water column as, after glacial melting the lake was filled with water highly saturated with oxygen. Consequently, it promoted the growth of water vegetation which first produced oxygen. However, due to the shallow depth of the lake it began to overgrow and eventually consumed more oxygen than produced, hence the significant drop of $\mathrm{Mn} / \mathrm{Fe}$ ratio which is evident at the depth of 1.4-1.5 meters of sapropel layers.

Seven pollen zones (Artemisia, Betula, Pinus, Ulmus-Tilia, Alnus Betula, Picea-Pinus and Pinus-Betula$N A P$ ) are distinguished in the pollen diagram (Fig. 7). The base layers (depth 2.3-2.6m) of this lake were accumulating when the climate was cold and dry (Artemisia, Betula LPAZ, Younger Dryas-Borealis 
chronozones (Fig. 7). These conditions were favourable for physical weathering and accumulation of more mineral matter.

Layers at depths of $0.8-2.0$ were forming during the Atlantic to Subboreal chronozones and these sediments are characterized by higher amounts of organic matter (Fig. 6). Sediments of the uppermost at the bottom of the lake to a depth $0.8 \mathrm{~m}$ are attributed to modern times and therefore are enriched by heavy metals as explained above.

Lake Gineitiškès is also situated in the urbanized area and has received an anthropogenic load. The sediments of the lake were cored to a depth of $9.1 \mathrm{~m}$. The amounts of organic matter are slightly higher in deeper layers than the upper. Concentrations of $\mathrm{Zn}$ are quite high (Fig. 8) in all layers of sapropel, but do not exceed the MAC. Higher concentrations of $\mathrm{Zn}$ are related directly to higher amounts of organic matter $(r=0.76, p<0.05)$.

Concentrations of $\mathrm{Pb}$ and $\mathrm{Cu}$ were detected in all core samples with higher concentrations in the upper sapropel layers. It clearly shows the impact of anthropogenic inputs. $\mathrm{Cr}$ concentrations exceed the MAC by 3.17 times. The high concentrations were determined in the layer of sapropel from the lake bottom down to the depth of 1.0 meter. These concentrations might be due to migration of chemical elements since the sapropel contains up to $95 \%$ of water.

Concentrations of heavy metals were also influenced by very variable redox conditions since the ratio of $\mathrm{Mn} / \mathrm{Fe}$ changes from bottom to the top of the sediment layers in a wide range (Fig. 8). Oxygen concentrations were increasing from the bottom layers of sapropel to 2.5 meters, but then drastically dropped and then remained low until the present. This clearly shows the changes of anthropogenic activity in the catchment area of the lake. The lake became shallow and overgrown with low clarity of the water and with no possibility of enriching the water column with oxygen. The association matrix shows the similar correlations to those at Lake Salote (Fig. 11). The main associations $(r=0.76-0.96, p<0.05)$ of chemical elements were formed by mineral matter (with exception of $\mathrm{Zn}$ ). This proves that eutrophic lakes when under the influence of anthropogenic loads are characterized by similar chemical compositions and widely fluctuating changes through the whole sediment core.

The sampled section for pollen was $4.4 \mathrm{~m}$ deep and in that interval three local pollen assemblage zones (Alnus-Quercus-Corylus, Betula-Pinus, Pinus-NAP) have been distinguished. However this section is characterized by minor changes in pollen data (Fig. 9). Pollen data of the depth interval of the core 3.7$4.4 \mathrm{~m}$ (Alnus-Quercus-Corylus LPAZ) shows a quite warm climate and favourable conditions for accumulation of organic matter so this layer is attributed to the Subboreal chronozone. In the depth interval $1.2-3.7 \mathrm{~m}$. a decrease of broad leaved trees and increase of grass coverage are observed so this section is attributed to the Subatlantic chronozone. The uppermost section (up to depth $1.2 \mathrm{~m}$ ) is characterized by a significant increase of grass coverage (Pinus-NAP LPAZ) that was influenced by climate conditions as well as by changes of land use and increased agriculture. The radiocarbon ${ }^{14} \mathrm{C}$ date of the sample from the depth $0.4-0.6 \mathrm{~m}$ is $1075-925 \mathrm{cal} \mathrm{yr}$ BP which suggests that human activities were 
present around Lake Gineitiškès a thousand years ago. The geochemical traces of anthropogenic activity are evident in the sapropel section up to $1 \mathrm{~m}$ depth as discussed above.

In natural lakes that were later affected by human activities, the main association of chemical elements in sapropels is formed by biophylic elements (Fig. 10) Fe, Mn, Zn, K, Ca which are associated with the strongest correlation $(r=0.75-0.98, p<0.05)$ together with minerogenic elements $\mathrm{Sr}$ and $\mathrm{Rb}$. The clastogenic elements $\mathrm{Ti}, \mathrm{Rb}, \mathrm{Zr}$ together with the biophylic elements $\mathrm{Zn}, \mathrm{K}, \mathrm{Mn}, \mathrm{Fe}(r=0.67-0.97, \mathrm{p}<0.05)$ form the main association of sapropel chemical elements in the different paleo-environmental conditions. The concentration of $\mathrm{Zn}$ is determined by the accumulation of organic matter $(r=0.84, p$ $<0.05$ ). Thus, the associations and distribution of the chemical elements in sapropel of lakes that are influenced by anthropogenic activity (Fig. 11) depend on the changes of the amount of mineral matter and land use and industrial patterns. Mobile elements such as as $\mathrm{Pb}, \mathrm{Cr}, \mathrm{Cu}$, together with lithogenic elements $(\mathrm{Ti}, \mathrm{Rb}, \mathrm{Sr}, \mathrm{Zr})$ show the strongest correlations $(r=0.62-0.97, \mathrm{p}<0.05)$.

\section{Discussion}

The geochemistry of sapropels in lakes studied in Lithuania was analysed. Results demonstrated a high natural variability of all elements but with significant impacts of anthropogenic activities that are evident in upper layers formed in recent times. Changes in the structure of catchment vegetation strongly affected the proportion of organic and mineral matter as well as geochemistry of lake sediments (c.f. Giguet-Covex et al. 2011; Haas et al. 1998). A multiproxy approach in analysis of lake sediments allows not only the reconstruction of climatic and water level changes in lakes, but also reveals changes in weathering and erosion patterns in the associated catchment areas. These processes determine the geochemistry and physical composition of lake sediments as well as sedimentation rates (c.f. Kurzo et al. 2004; Canavan et al. 2007).

The sapropel of eutrophic lakes (Salotè and Gineitiškès) is shown to be enriched with heavy metals ( $\mathrm{Pb}$, $\mathrm{Cr}, \mathrm{Cu}, \mathrm{Zn}$ ). Two main elements $\mathrm{Cr}$ (from 1.7 to 3.17 times) and $\mathrm{Zn}$ (up to 1.48 times) exceed the MAC in various, mostly the upper, layers of the sapropel. Due to the adjacent presence of clay minerals sapropel can be enriched by heavy metals ( $\mathrm{Cr}, \mathrm{Zn}$ ) in deeper layers as well. In previous studies, authors have stated that the enrichment of sediments with heavy metals is not only related to anthropogenic activity, but it also depends on the nature of geological layers that occur in different regions (Petersen et al. 1997; Wang et al. 2012). Nevertheless, interrelations of heavy metals and associations with organic and mineral matter can depend on vegetation, anthropogenic load, depth and bottom relief of lakes as well as the nature of geological layers and geomorphology of the catchment area of the lake.

The observed main correlations of chemical elements identified two different compositions of sapropel in contaminated and relatively clean lakes. Sapropel with high concentrations of heavy metals forms lithogenic association of chemical elements - mineral matter, $\mathrm{As}, \mathrm{Fe}, \mathrm{Cr}, \mathrm{Pb}, \mathrm{Ti}, \mathrm{K}, \mathrm{Zr}, \mathrm{Sr}, \mathrm{Rb}$ - with $\mathrm{r}=0.76$ to $0.96, p<0.05$. The other association with organic matter $-\mathrm{Zn}, \mathrm{Mn}, \mathrm{Sc}, \mathrm{Ca}$ - varies from $r=0.36$ to $0.76, \mathrm{p}$ $<0.05$. Sapropel with low concentrations of heavy metals has a different "mixed-association" matrix. 
Most of the elements tend to form mixed complexes in organic parts of sediments (organic matter, $\mathrm{Zn}$, Fe, $\mathrm{Zr}$, Ti, Rb, K with $\mathrm{r}=0.69$ to $0.98, \mathrm{p}<0.05)$, whereas elemental associations of mineral matter are associated with $\mathrm{As}, \mathrm{Mn}, \mathrm{Sr}$, Ca and correlation values vary from $r=0.47$ to $0.89, \mathrm{p}<0.05$. Similar distribution and relation patterns of lake sediment geochemistry have been identified by other authors (Moberly et al. 2016; Javed et al. 2018).

It is noteworthy that variations of concentrations of heavy metals are influenced not only by anthropogenic activity, but also geochemical processes. Complex analysis reveals the sensitive relations of chemical elements which are bound into sediments which reflect both the anthropogenic load and the natural evolution of lake environments. The results of chemical analysis in lake sediment core samples also showed the influence of different lake parameters (depth, surrounding catchment area, sedimentation rate, etc.) to migration of chemical elements, which create the different correlation matrixes and bonding components in organic and mineral matter. Concentrations of heavy metals together with lithogenic elements clearly demonstrate changes in water level, changes in redox potential and development of surroundings in catchment area.

The pollen analysis revealed that sapropel in these lakes was formed mainly in Subboreal and Subatlantic chronozones of the Holocene (Fig. 12). DR3 - Younger Dryas, BO - Boreal, AT - Atlantic, SB Subboreal, SA - Subatlantic, Mo T - modern times. Changes in vegetation structure during alternating warm, cold, wet and dry climates influenced the different conditions mainly physical and chemical weathering intensities (Schnurrenberger et al. 2003; Rūtina et al. 2012). These processes directly influenced the sedimentation changes in lakes and the resulting chemical composition of sapropels.

Investigation of the formation of sediments in selected lake ecosystems in Lithuania provides records of natural changes as well as anthropogenic impacts on the environment and provides perspectives for better management of lacustrine natural resources. While anthropogenic effects are significant it should be recognised that natural environment conditions can also cause increased concentrations of heavy metals and other chemical elements. All of the lakes are located in the same geographical region and have experienced similar paleoclimate conditions however their pollen assemblage zones slightly differ due to local biogeographic conditions, lithology and soils, hydrography, catchment area and other factors. Due to these local conditions different rates of accumulation of sediments have existed and this is demonstrated by different thickness of the layers belonging to the same chronozone (Fig. 12).

The anthropogenic impacts can still be traced despite the absence of any heavy industry and mainly due to household and transport activities e.g. at Lake Gineitiškès. The contaminated layers in further investigation have to be examined in more detail, applying much shorter intervals of sampling and applying precise chronology (e.g. ${ }^{210} \mathrm{~Pb}$ dating).

All lakes are located in the same geographical region and they did pass actually through similar paleoclimate conditions, however their pollen assemblage zones slightly differ due to local biogeographic conditions, lithology and soils, hydrography, catchment area and other factors. Due to these local 
conditions different rates of accumulation of sediments have existed and this is evidenced by different thickness of the layers belonging to the same chronozone (Fig. 12).

\section{Declarations}

\section{Ethics approval and consent to participate}

Authors have no conflicts on ethics approval and give the consent to participate.

\section{Consent to publication}

Authors give the consent to publication.

\section{Availability of data and material}

Authors ensure the availability of data and material.

\section{Competing interests}

Authors have no competing interests.

\section{Funding}

Authors ensure that there are no conflicts on funding.

\section{Authors' contributions}

Jonas Satkūnas - managed all the process of the methodological approach. Made analysis and discussion on geological and paleoenvironment perspective in regard of radiocarbon dating.

Vaidotas Valskys - made analysis of concentrations of heavy metals as well as discussion on geochemical interactions on anthropogenic induced changes and paleoenvironment influence.

Gytautas Ignatavičius - made analysis of the data on environmental impact. Contributed in making insights of interactions of pollution and potential sources.

Alma Grigienè - made palynological analysis and discussion on changes of paleoenvironment.

\section{Acknowledgements}

The authors thank Dr. Brian Marker (UK) for linguistic editing of the paper and also two unknown reviewers for their valuable remarks and suggestions.

\section{References}


Arnaboldi M, Meyers P A. Trace element indicators of increased primary production and decreased water column ventilation during deposition of latest Pliocene sapropels at five locations across the Mediterranean Sea. Palaeogeogr palaeocl. 2007;249:425-443.

Bradley RS. Paleoclimatology: Reconstructing Climates of the Quaternary. Academic Press, San Diego. 1999;2:610-618.

Brännvall ML, Bindler R, Emteryd O, Renberg I. Four thousand years of atmospheric lead pollution in Northern Europe: a summary from Swedish lake sediments. J Paleolim. 2001;25:421-435.

Canavan RW, Van Cappellen P, Zwolsman JJK, van den Berg GA, Slomp CP. Geochemistry of trace metals in a fresh water sediment: Field results and diagenetic modeling. Sci total environ. 2007;381:263-279.

Chondrogianni C, Ariztegui D, Bernasconi SM, Lafargue E, Mckenzie JA. Geochemical indicators tracing ecosystem response to climate change during the late Pleistocene (Lake Albano, central Italy). Mem Ist ital Idrobiol. 1996;55:99-109;

Damušytė A. Post-Glacial geological history of the Lithuanian coastal area. Summary of doctoral dissertation. Physical sciences, geology (05P). Vilnius University. 2011;84.

Davison W. Iron and manganese in lakes. Earth Sci Rev. 1993;34:119-163.

de Boer J, van der Zande TE, Pieters H, Ariese F, Schipper CA, van Brummelen T, Vethaak AD. Organic contaminants and trace metals in flounder liver and sediment from the Amsterdam and Rotterdam harbours and off the Dutch coast. J environ monitor. 2001;3(4):386-393.

Domaševičius A, Giedraitienė J, Gregorauskienè V. Methodological recommendations. Lithuanian Geological Survey. Vilnius. 1999;43-45.

Gehrke GE, Blum DJ, Meyers AP. The geochemical behavior and isotopic composition of $\mathrm{Hg}$ in a midPleistocene western Mediterranean sapropel. Geochimica et Geochimica Acta. 2008;73:1651-1665.

Giguet-Covex C, Arnaud F, Poulenard J, Disnar JR, Delhon C, Francus P, David F, Enters D, Rey PJ, Delannoy $\mathrm{JJ}$. Changes in erosion patterns during the Holocene in a currently treeless subalpine catchment inferred from lake sediment geochemistry (Lake Anterne, $2063 \mathrm{~m}$ a.s.I., NW French Alps): The role of climate and human activities. Holocene. 2011;21(4):651-665.

Granina L, Müller B, Wehrli B. Origin and dynamics of Fe and Mn sedimentary layers in Lake Baikal. Chem geol. 2004;205:55-72.

Gryguc G, Kisielienė D, Stančikaitė M, Šeirienè V, Skuratovię Ž, Vaitkevičius V, Gaidamavičius A. Holocene sediment record from Briaunis palaeolake, Eastern Lithuania: history of sedimentary environment and vegetation dynamics. Baltica. 2013;26(2):121-136. 
Groundwater of Lithuania. Hydrogeological Atlas. Compiled by Kadūnas K, Pūtys P, Gedžiūnas P. Lithuanian Geological Survey. 2018.

Guobytè R, Satkūnas J. Pleistocene Glaciations in Lithuania // Quaternary Glaciations - Extent and Chronology: A Closer Look. - Amsterdam: Elsevier. 2011;231-246.

Haas JN, Richoz I, Tinner W and Wick L. Synchronous Holocene climatic oscillations recorded on the Swiss Plateau and at the timberline in the Alps. Holocene. 1998;8:301-309.

Heikkila M, Seppa H. Holocene climate dynamics in Latvia, eastern Baltic region: a pollen-based summer temperature reconstruction and regional comparison. Boreas. 2010;39:705-719.

Javed T, Ahmad N, Mashiatullah A. Heavy metals contamination and ecological risk assessment in surface sediment of Namal Lake, Pakistan. Pol. J. Environ. Stud. 2018;27(2):675-688.

Kabailienè M. Gamtinès Aplinkos raida Lietuvoje per 14000 metų (Environmetal development in Lithuania during the past 14,000 years. Mokslas, Vilnius. 2006;471.

Koinig KA, Shotyk W, Lotter AF, Ohlendorf C, Sturm M. 9000 years of geochemical evolution of lithogenic major and trace elements in the sediment of an alpine lake - the role of climate, vegetation, and land-use history. J Paleolimnol. 2003;30:307-320.

Kurzo B, Hajdukiewicz O, Krasnoberskaya 0.) Relationships of sapropel formation in lake-mire complexes of Belarus. Limnological Review. 2004;4:125-132.

Lepane V, Varvas M, Viitak A, Alliksaar T, Heinsalu A. Sedimentary record of heavy metals in Lake Rõuge Liinjarv, southern Estonia. Est J Earth Sci. 2007;56(4):221-232.

[LME] Lithuanian Minister of Environment. The Requirements for the Management of Surface Water Bodies. Order No. D1-1038 2014.12.16, Vilnius. 2004;5.

Mimba, M.E., Ohba, T., Nguemhe Fils, S.C. et al. Regional geochemical baseline concentration of potentially toxic trace metals in the mineralized Lom Basin, East Cameroon: a tool for contamination assessment. Geochem Trans. 2018;19,11.

Moberly J, D' Imperio S, Parker A, Peyton B. Microbial community signature in Lake Coeur d'Alene: Association of environmental variables and toxic heavy metal phases. Appl Geochem. 2016;66:174-183.

Moller T, Schulz H, Hamann Y, Dellwig O, Kucera M. Sedimentology and geochemistry of an exceptionally preserved last interglacial sapropel S5 in the Levantine Basin (Mediterranean Sea). Mar Geol. 2012;291294.

Naeher S, North RP, Gilli A, Livingstone DM, Schubert CJ. Highlights of Analytical Sciences in Switzerland. Chimia. 2014;(68)5:333. 
Ong MC, Menier D, Shazili NAM, Kamaruzzaman BY. Geochemical characteristics of heavy metals concentration in sediments of quiberon bay waters, South Brittany, France. Oriental Journal of Chemistry. 2013;29(1):39-45.

Order of Director of Lithuanian Geological Survey under Ministry of Environment. No. 1-190, 29-09-2016. "On approval of classification of aquatic sediments". Vilnius.

Petersen W, Willer E, Willamowski C. Remobilization of trace elements form polluted anoxic sediments after resuspension in oxic water. Water Air Soil Poll. 1997;99:515-522.

Rūtiṇa L, Ceriṇa A, Stankeviča K, Kḷaviṇš M. Character of paleovegetation change in Lakes Pilcines, Pilvelu and Padēlis. Acta Biologica, University of Daugavpils, Suppl. 2012;3:94-107.

Schnurrenberger D, Russell J, Kelts K. Classification of lacustrine sediments based on sedimentary components. J Paleolimnol. 2003;29:141-154.

Shotyk W, Weiss D, Appleby PG, Cheburkin AK, Frei R, Gloor M, Kramers JD, Reese S, Van der Knaap WO. History of atmospheric lead deposition since 12,370 C-14 yr BP from a peat bog, Jura Mountains, Switzerland. Science. 1998;281:1635-1640.

Stankevica K, Klavins M. Sapropel and Its Application Possibilities. Materials Sciences and Applied Chemistry. 2013;29:109-126.

Stankevica K, Pujate A, Kalnina L, Klavins M, Cerina A, Drucka A. Records of the anthropogenic influence on different origin small lake sediments of Latvia. Baltica. 2015;(28)2:135-1142.

Stumm W, Morgan JJ. Aquatic Chemistry. Chemical Equilibria and Rates in Natural Waters. Wiley and Sons, NewYork. 1996;1022.

Tylmann W, Łysek K, Kinder M, Pempkowiak J. Regional pattern of heavy metal content in lake sediments in Northeastern Poland. Water Air Soil Poll. 2011;216:217-228.

Wang Y, Hu J, Xiong K, Huang X, Duan S. Distribution of heavy metals in core sediments from Biahua Lake. Procedia Environ Sci. 2012;16:51-58.

Zhu GW, Qin BQ, Gao G, Luo L, Wang W. Accumulation characteristics of heavy metals in the sediments of Lake Taihu, China. Journal of Lake Science. 2005;17(2):143-145.

\section{Figures}




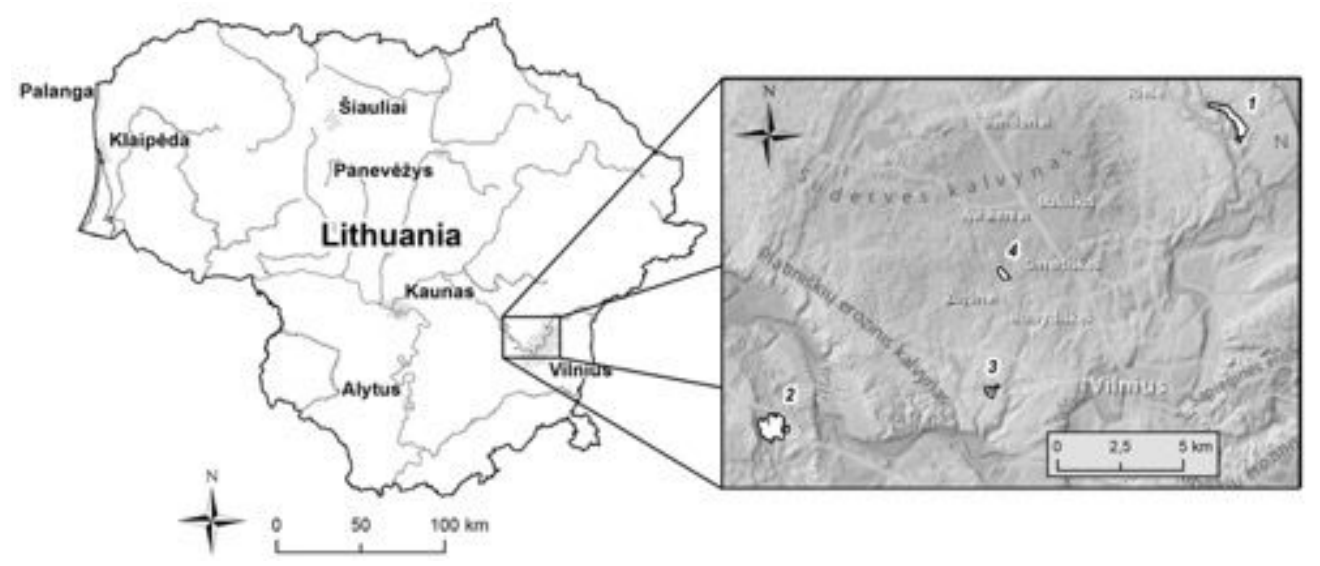

Figure 1

Location of investigated lakes: 1 - Balsys, 2 - Didžiulis, 3 - Salotè, 4 - Gineitiškès

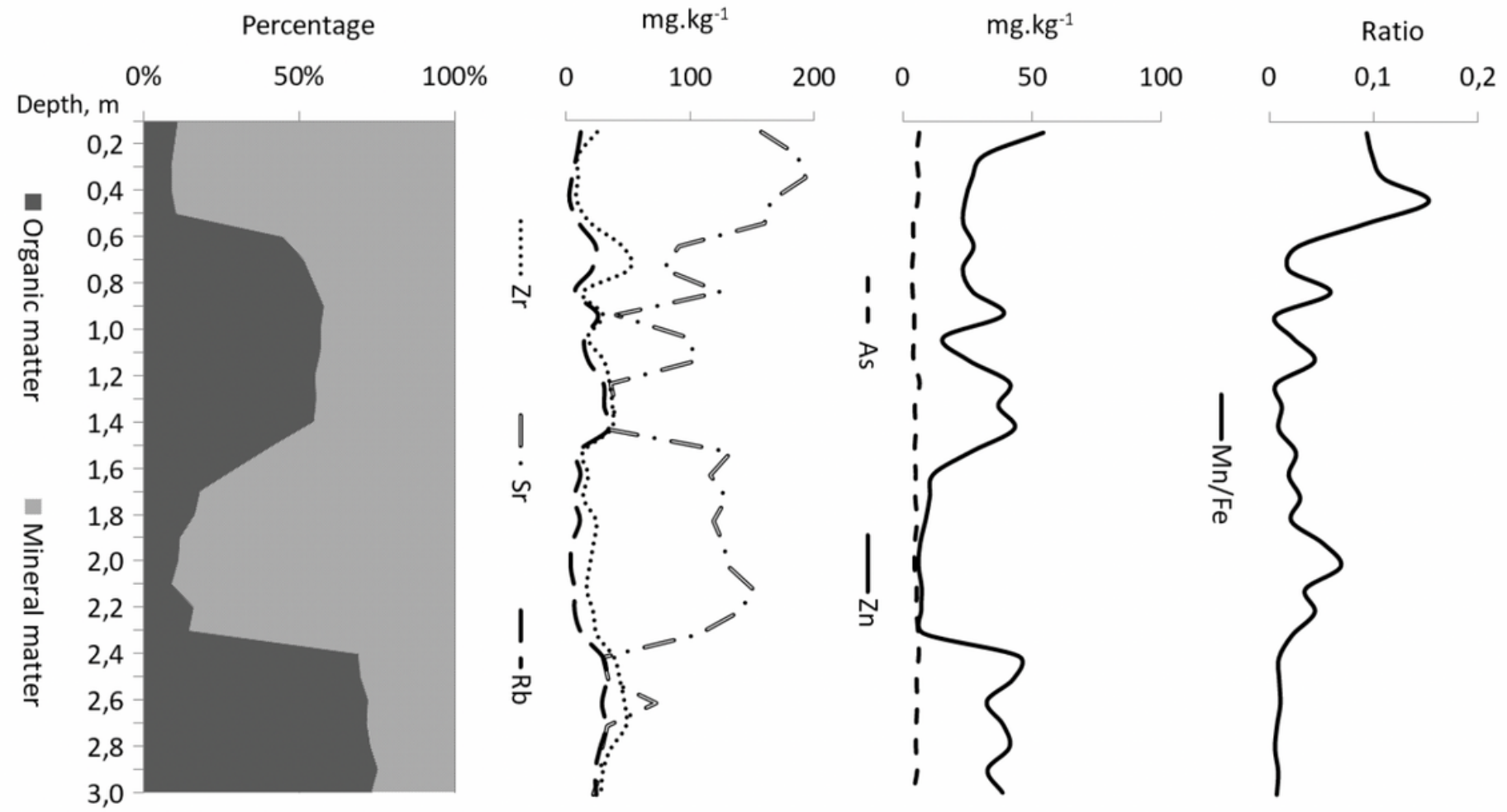

Figure 2

Concentrations of heavy metals in sediments of the lake Balsys 


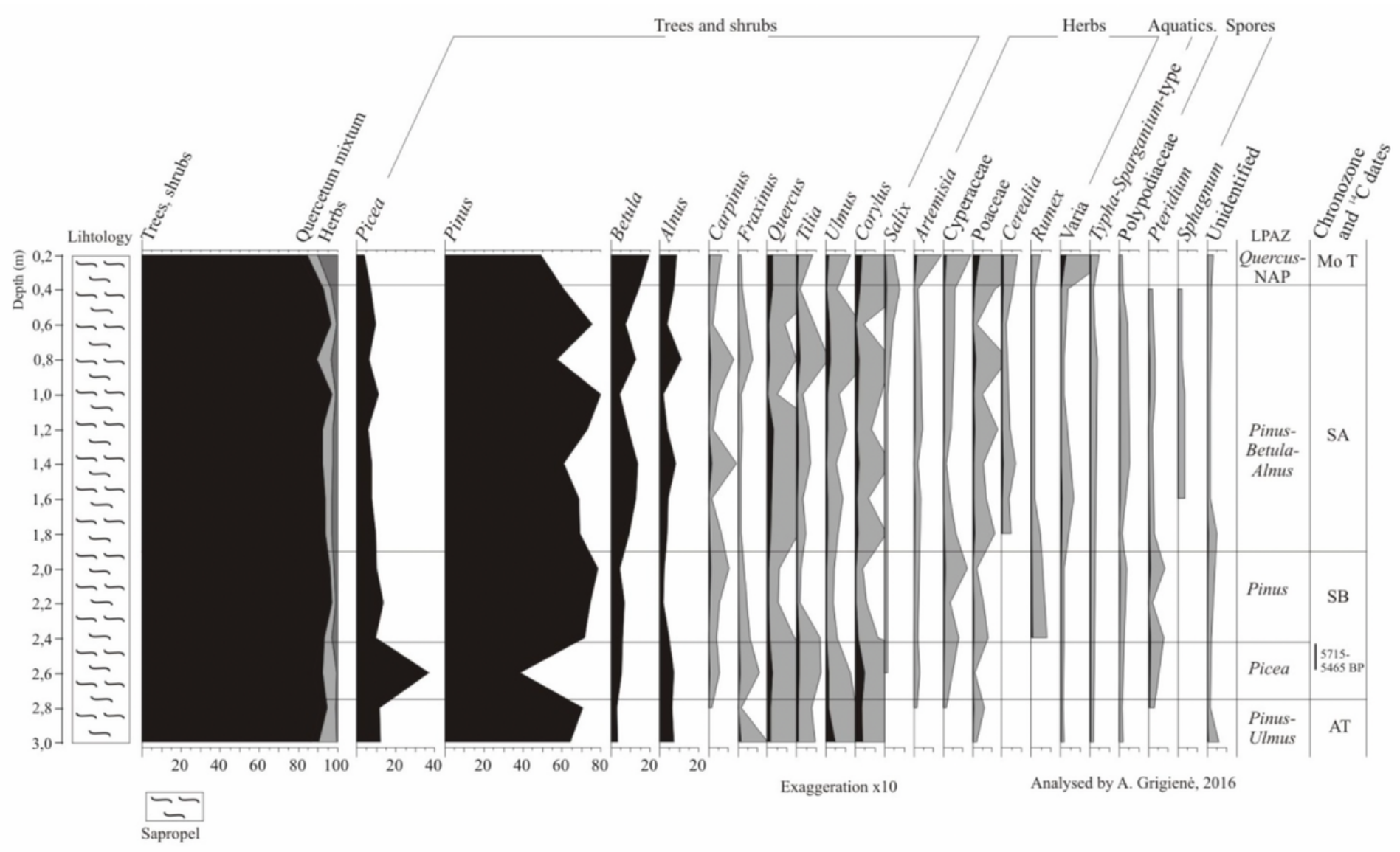

Percentage pollen diagram of Lake Balsys

Figure 3

Percentage pollen diagram of the core of lake Balsys

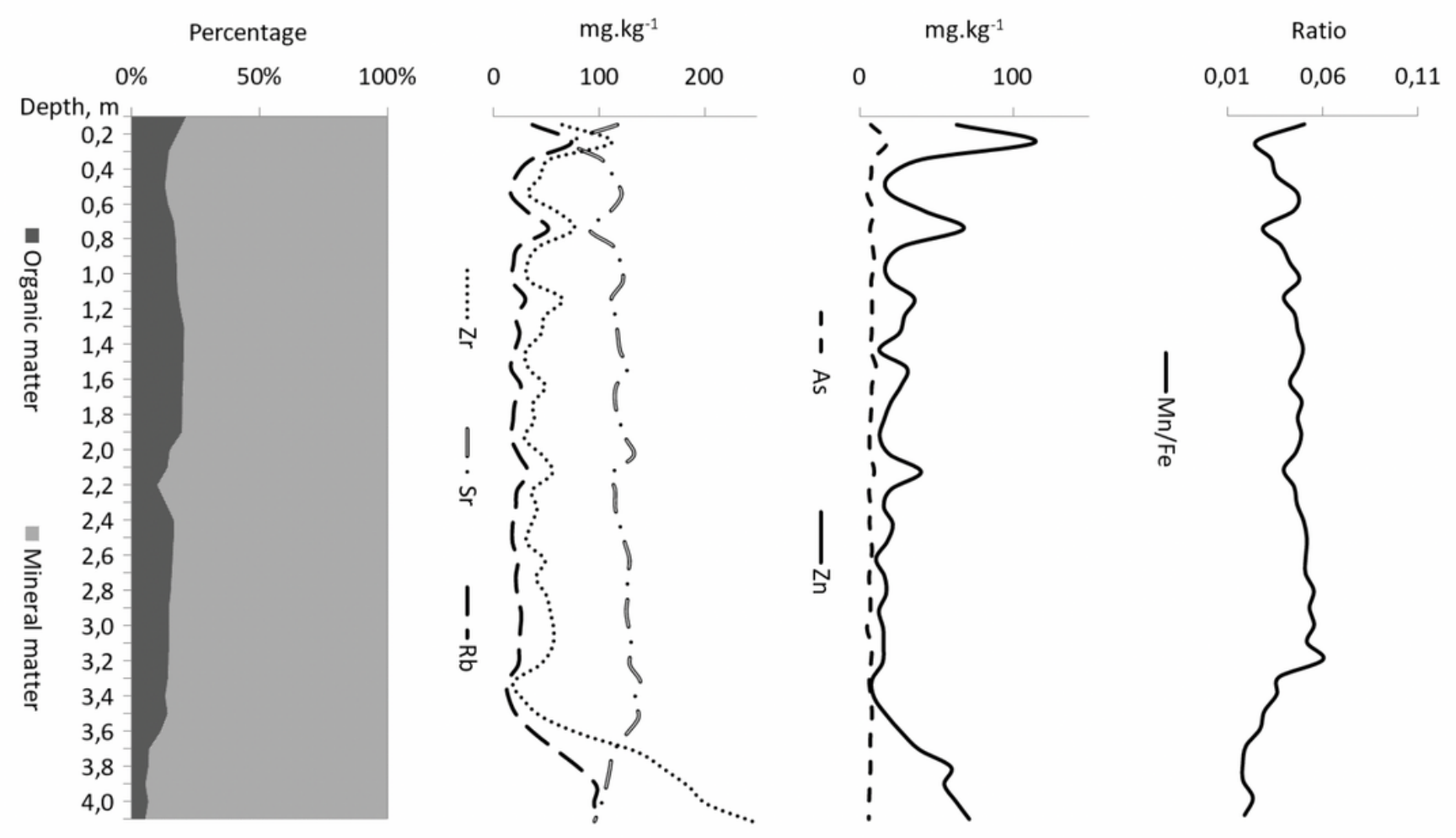


Figure 4

Concentrations of heavy metals in sediments of lake Didžiulis

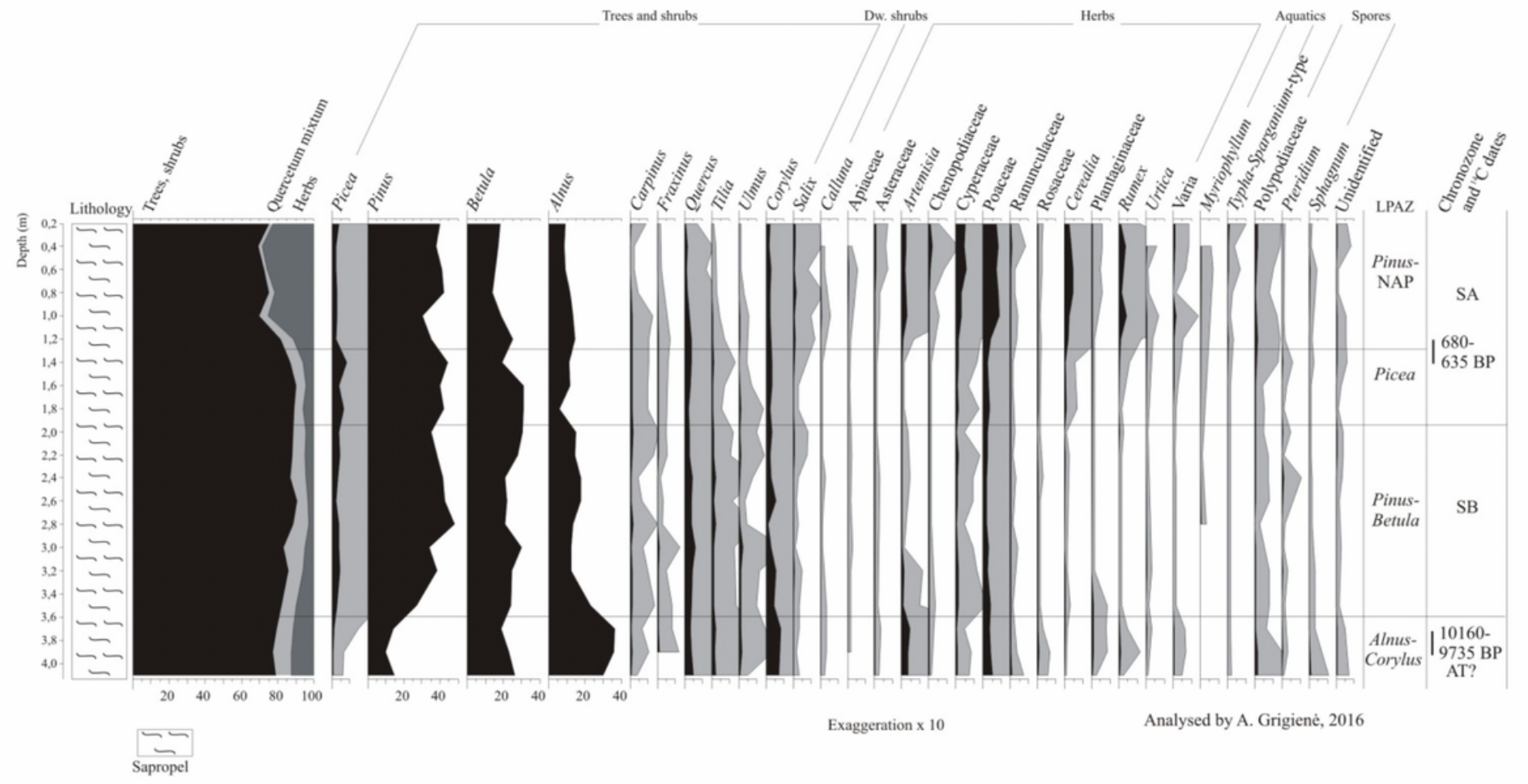

Percentage pollen diagram of Lake Didžiulis

Figure 5

Percentage pollen diagram of the core of lake Didžiulis

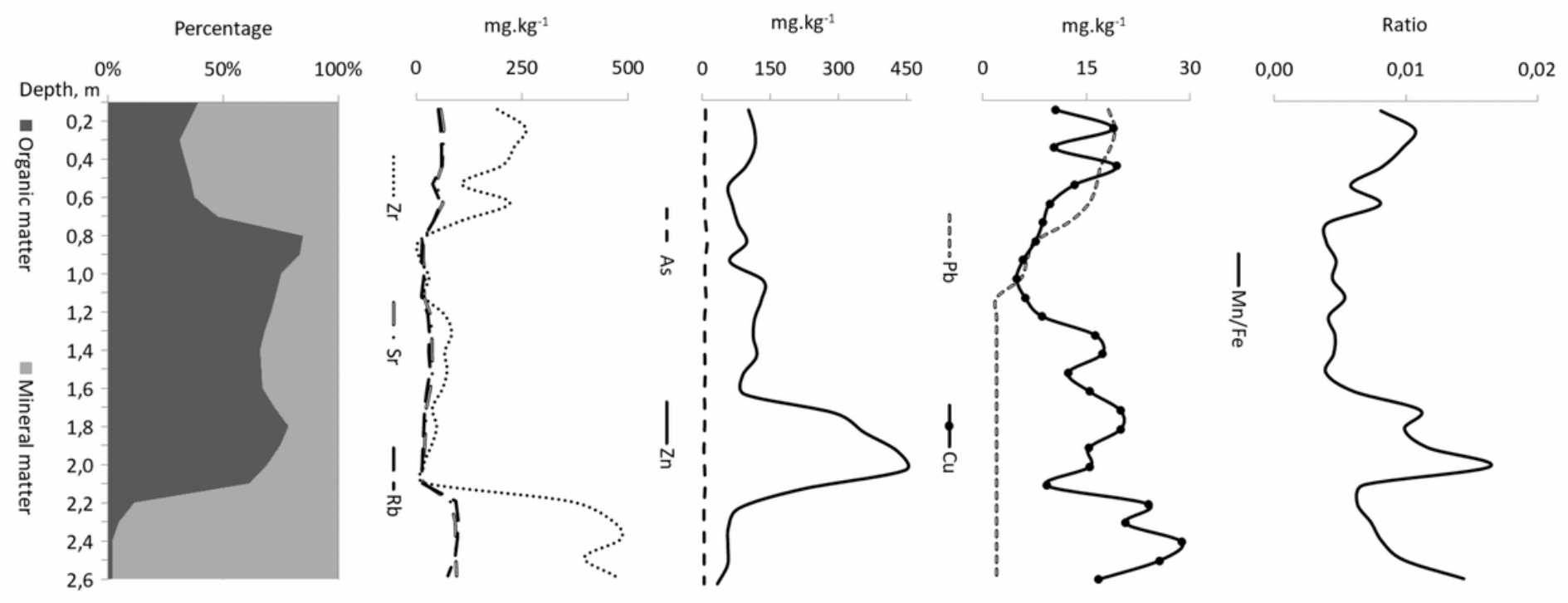

Figure 6

Concentrations of heavy metals in sediments of lake Salote 


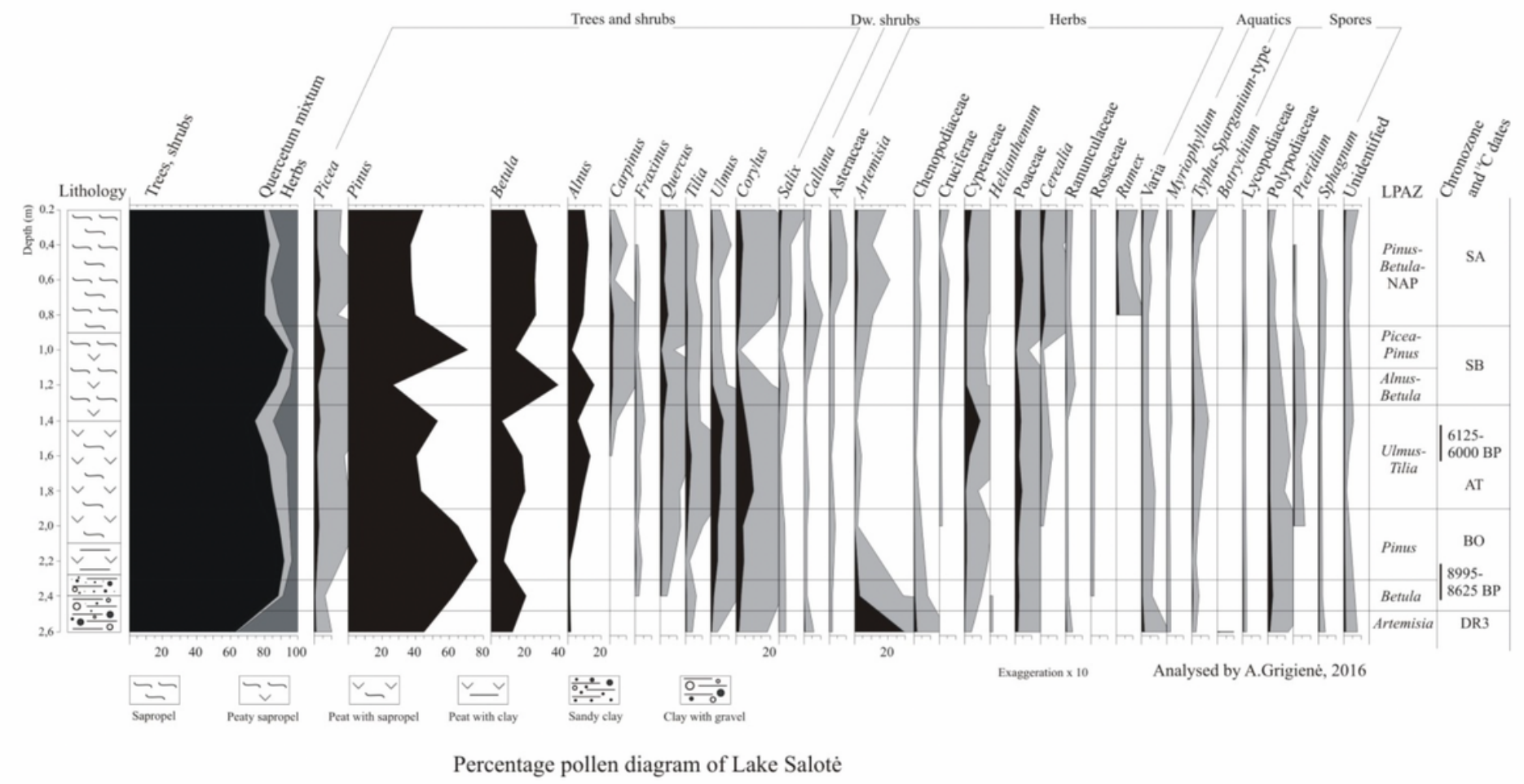

Figure 7

Percentage pollen diagram of the core of lake Salote

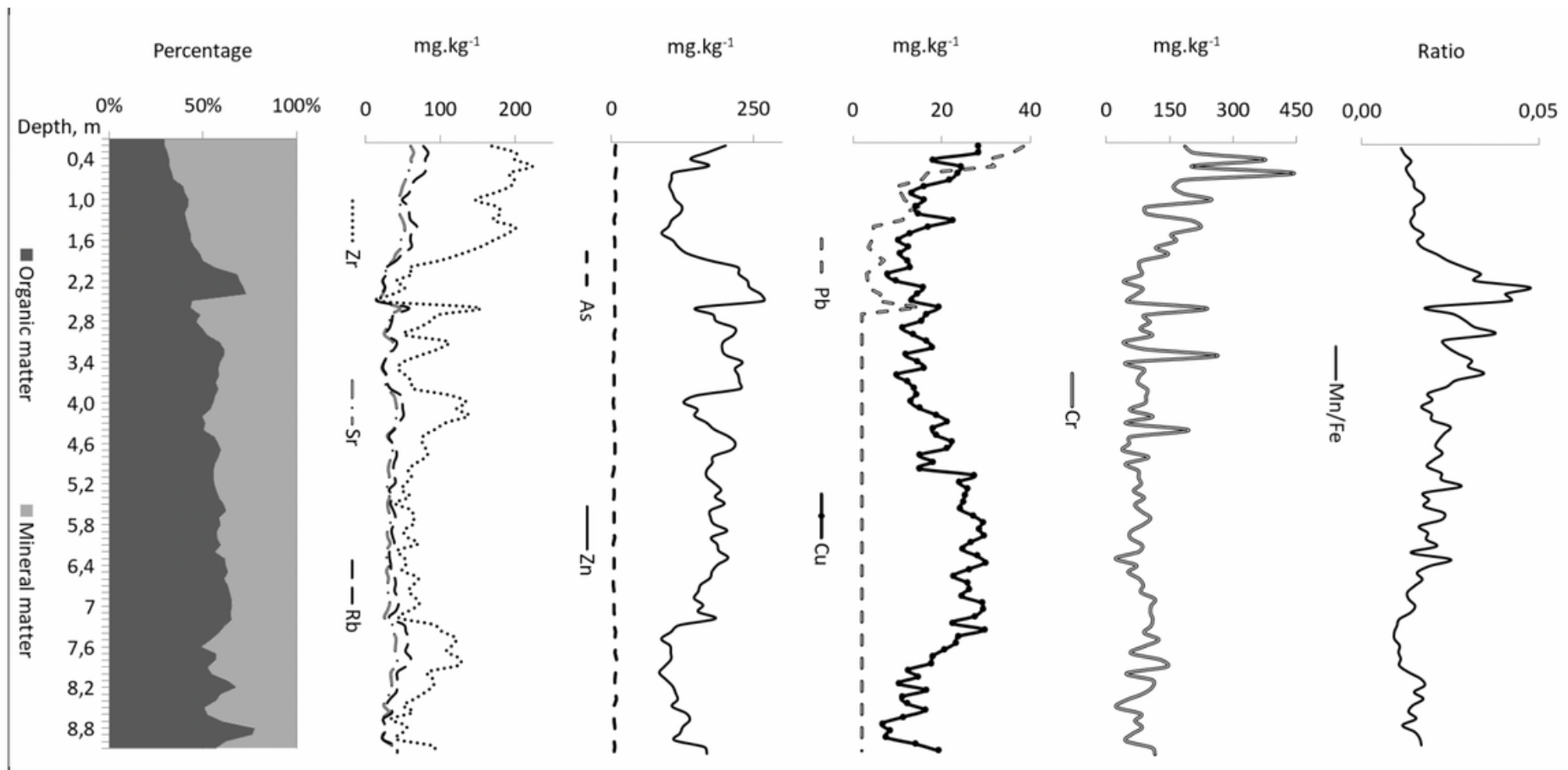

Figure 8

Concentrations of heavy metals in sediments of lake Gineitiškès 


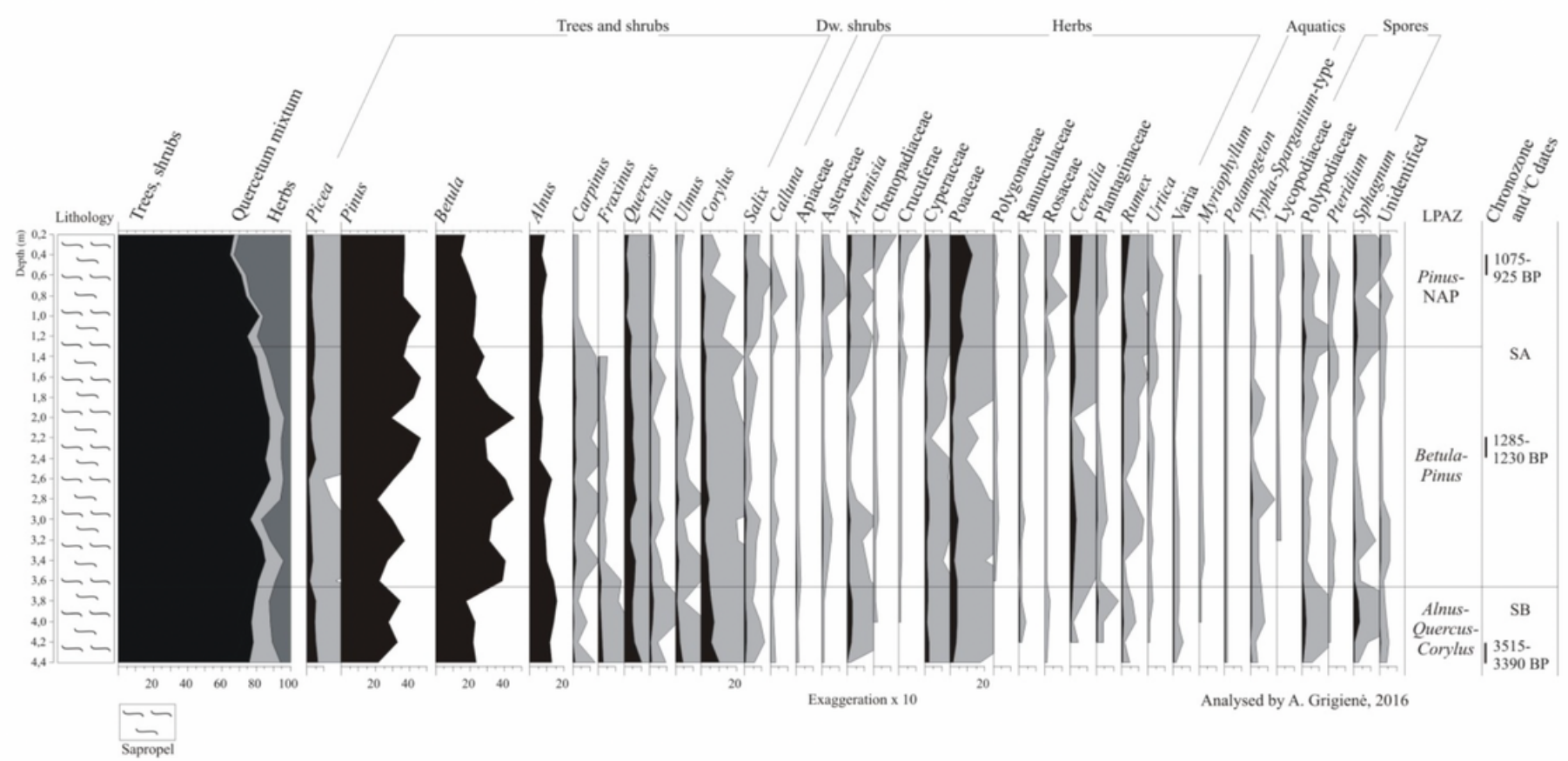

Percentage pollen diagram of Lake Gineitiškès

Figure 9

Percentage pollen diagram of the core of lake Gineitiškès
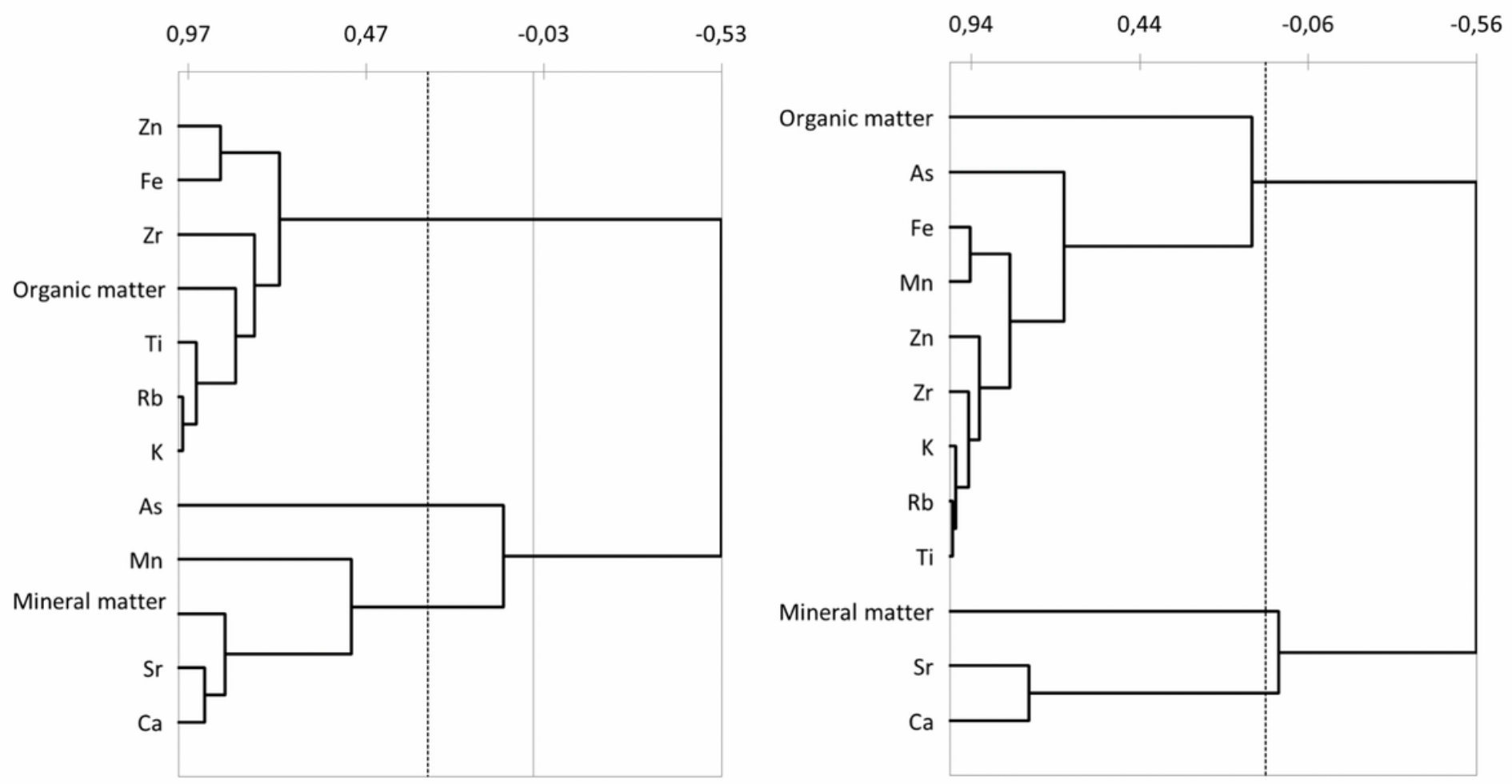

Figure 10

Cluster analysis (Spearmann correlation matrix, $\mathrm{p}<0.05)$ of data from Lakes Balsys and Didžiulis 

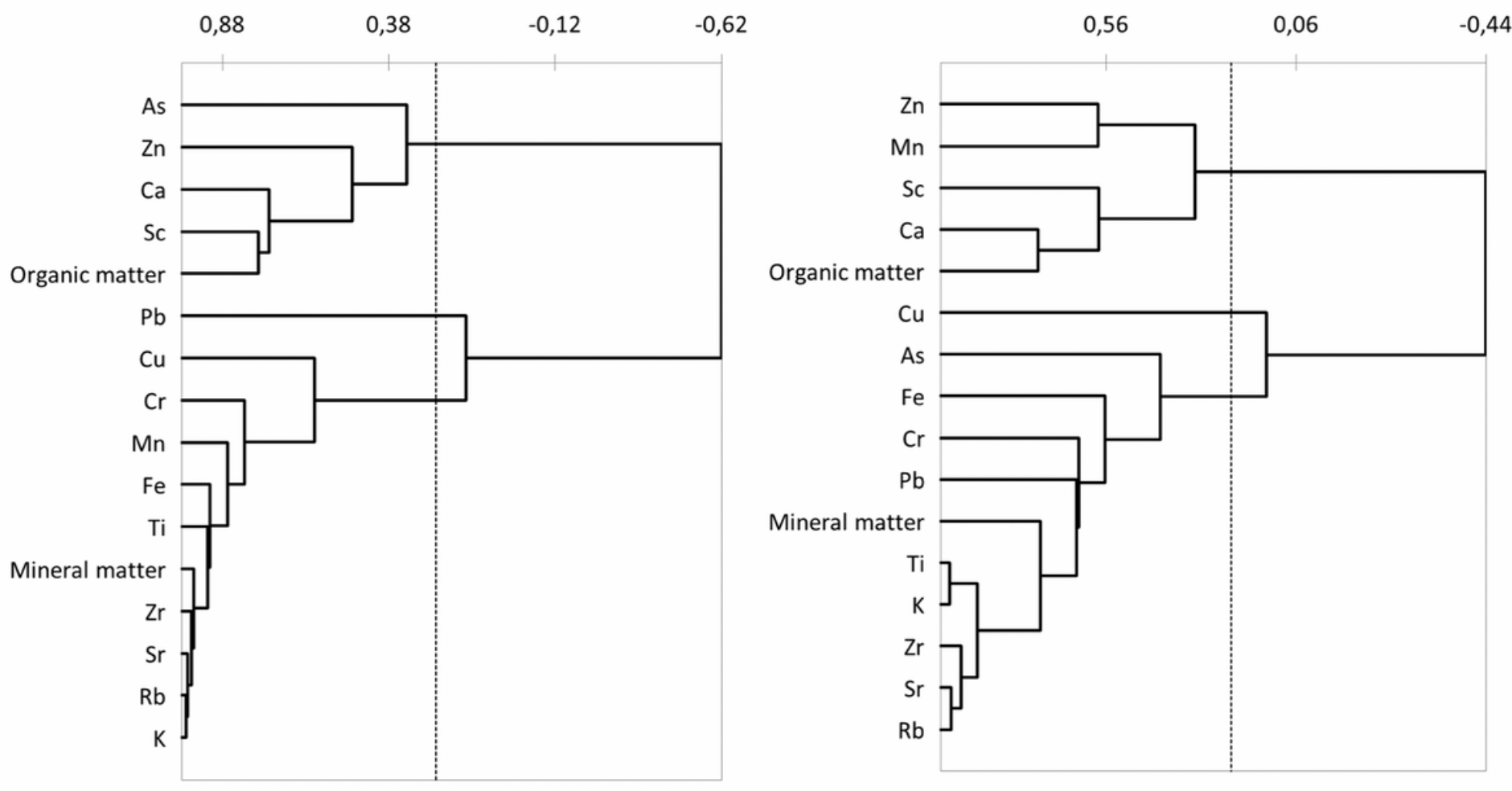

\section{Figure 11}

Cluster analysis (Spearmann correlation matrix, $\mathrm{p}<0.05)$ of data from Lakes Salotè and Gineitiškès 
Balsys

Didžiulis

Gineitiškès

Salotè

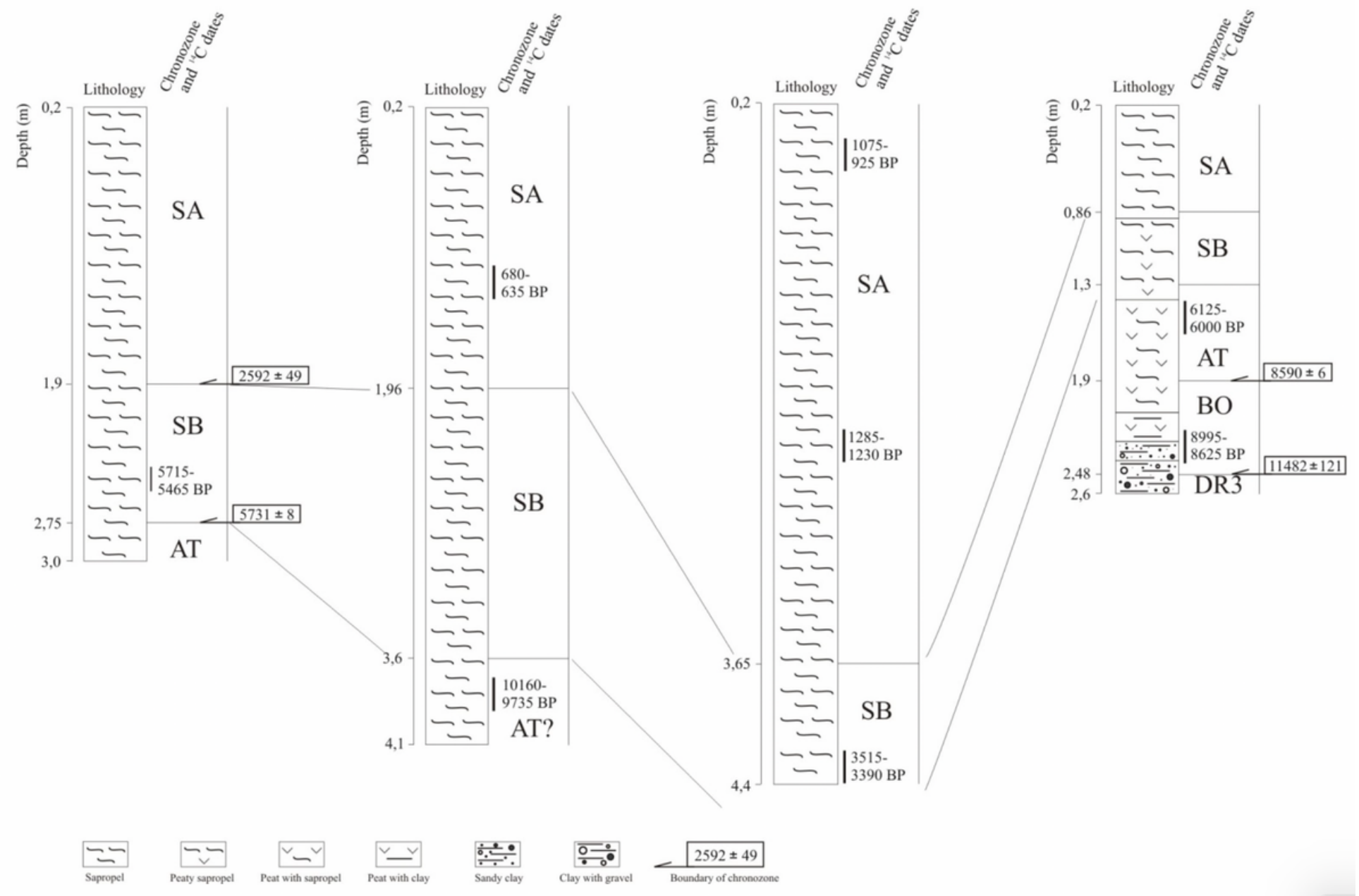

Figure 12

Correlation of chronozones of the sediments of the investigated lakes on the basis of pollen data and radiocarbon C14 datings. The boundaries of chronozones are given in calibrated years BP (Damušyte, 2011). 